\title{
A corpus-based study of directives in Taiwanese Southern Min [台灣閩南話指示行為：以語料庫為本的研究]
}

\author{
Miao-Hsia Chang [張妙霞] and Ún-giân Iûnn [楊允言] \\ National Taiwan Normal University [國立臺灣師範大學] \\ National Taichung University of Education [國立台中教育大學]
}

This study aims to examine the subtypes of directives and their realization patterns in Taiwanese Southern Min (TSM). The data were drawn from a play script corpus published in the 2oth century. Nine directive subtypes were identified: ADVICE, BEGGING, INVITATION, ORDER, OFFER, REQUEST, SUGGESTION, URGE, and WARNING. The realization patterns were analyzed in terms of the main components in the directives: alerter, discourse marker, politeness marker, subject, modal expression, verb phrase, and utterance final particle. The analysis reveals a number of features: (1) Alerters mainly take the form of an address term; (2) Utterance-initial discourse markers are mainly realized by $t a^{n}$ 'now'; (3) The subject is either hearer-dominated or speaker- and hearer-dominated, with the latter expressing solidarity in casual situations; (4) the politeness marker chhián tends to take an overt subject; (5) The modal verb tióh accounts for the majority of subtypes; (6) The dominant verb types include dynamic, stative, uttering, and ingesting verbs; (7) Complex verb constructions mainly include directional verbs, disposal markers, and benefactive verbs; (8) Directional verbs are pervasive across all directives. A metaphorical transfer is operative in the use of directional verbs. Those marking an action toward the speaker (e.g., lâi 'come') are strongly associated with a positive attitude, while those expressing movement away from the speaker (e.g., khì 'go') are highly connected to an adversative mood. The omnipresence of [lâi $\mathrm{V}]$ suggests that it has been conventionalized as a default bundle to express politeness.

Keywords: Taiwanese Southern Min, directives, speech act, request, corpus

關鍵詞：台灣閩南話、指示行為、言語行為、請求語、語料庫 


\section{Motivation and goals}

Research on the functional and pragmatic aspects of language owes a great deal to the philosophers Austin (1962) and Searle (1969), who argue that people do not only mean what they say, but that an utterance can also be used as a speech act to perform an action, that is, to carry an illocutionary force, apart from its referential meanings. Among the speech acts investigated by Austin and Searle, "directives" refers to acts that are "attempts...by the speaker to get the hearer to do something" (Searle 1979:13). Requests, which are a type of directive speech act (Searle 1979:5), have attracted the most attention from pragmaticists, particularly in terms of the degree of politeness conveyed by this speech act and its associated social variables (power, distance, degree of imposition) (Brown \& Levinson 1987). In light of Brown \& Levinson's work, Blum-Kulka, House \& Kasper (1989) conducted a cross-cultural pragmatics project analyzing requests in five languages in situations involving a number of social variables. Over the last four decades, the coding criteria developed by Blum-Kulka, House \& Kasper have inspired pragmaticists to embark on studies of requests in $\mathrm{L}_{1}$ and L2. In research on Mandarin Chinese, for example, scholars have focused on the requestive strategies used by children (e.g., Su 1988, Y. Chen 2010) and adults (e.g., Zhang 1995), the perception of politeness (e.g., Lee-Wong 1994), the influence of power, distance, and the degree of imposition on the choice of requests (e.g., Yu 1999, Lin 2009, Rue \& Zhang 2008, to name just a few). Another line of research, which is cognitively based, concerns the prototypicality of imperatives/directives (Thornburg \& Panther 1997, Panther \& Thornburg 1998, 1999, 2003, Takahashi 2012). Wierzbicka (1987) makes a finer distinction in her comprehensive analysis of the metalanguage used to define speech acts in terms of their semantic primitives. However, compared to the rich literature on requests in Mandarin, surprisingly little research has been undertaken to examine requests in Taiwanese Southern Min (TSM). Although K. Teng (2017) explores the syntactic structure, subject properties, modality and associated complements of imperatives, the focus is on negative imperatives in TSM. In this paper, we aim to elucidate the use of positive directives (hereafter, directives) in TSM. Using the data drawn from the play scripts in the corpus Digital Archive Database for Written Taiwanese (DADWT), the following research questions are addressed:

1. What are the subtypes of directives in TSM?

2. What are the linguistic realizations of different components of directives in each subtype?

3. How are the linguistic components similar to and different from those used in Mandarin Chinese and English? 
4. What is the significance of the linguistic characterization of TSM directives in terms of language use in general?

The remainder of this paper is organized as follows. Section 2 reviews studies on requests and imperatives. As a full review would be beyond the scope of this paper, we discuss selected works relevant to the present study. Section 3 provides operational definitions of the subtypes of directive speech acts. Section 4 describes the data and the coding criteria used in this study. Section 5 presents the results and findings of the analysis. Finally, Section 6 concludes the study.

\section{Studies of requests}

Requests are a type of directive speech act. Instead of "directives", the term "requests", however, has been used as a general term in $\mathrm{L}_{1} / \mathrm{L} 2$ pragmatics research to cover directive speech acts such as commands, orders, advice, suggestions, pleas, and warnings. Although not explicitly stated, these studies have in fact investigated strategies in making positive requests, as they require the hearer's "future effort" to do something (Blum-Kulka, House \& Kasper 1989: 11-12).

Aimed at novice learners of Chinese L2 speakers, Shei (2014) presents a succinct list of the key features of directives. First, in Mandarin adverbs can be placed in front of the verbs, e.g., Man zou (slow-walk) 'Walk slowly', whereas adverbs tend to be placed post-verbally in English. Second, honorific terms such as qing 'please' and qiu '(I) beg (you)' are used in formal occasions, without which the request sounds impolite. Third, second person subjects are dominant. Fourth, the first person plural women 'we' can appear in a command or suggestion, e.g., Women zou 'Let's go'. As will be shown in Section 5 , these features are also shared by TSM directives.

Rather than focusing on the linguistic realizations of components in directives, most research on requests has investigated requests in terms of degrees of (in)directness and politeness and their correlation with social variables. One of the most influential volumes is Blum-Kulka, House \& Kasper (1989), which presents the results of a research project, i.e., the Cross-Cultural Speech Act Realization Project (CCSARP), the goal of which was to investigate cross-cultural variations in requests and apologies. The data were drawn from Discourse Completion Tests (DCT) for two social variables ( \pm Distance, \pm Power) across five languages. Three components of a request sequence are identified: alerters, supportive moves, and head acts. An alerter is an opening element such as an address term or attention getter (e.g., excuse me). A supportive move is an external unit modifying the impact of a request (p.276). The head act is the 
central component which realizes a given speech act "independently of other elements" (p.17).

Three levels of directness are distinguished: direct strategies, where "the degree to which the speaker's illocutionary intent is apparent from the locution" (p.278), conventionally indirect strategies (suggestory formula, e.g., How about cleaning up the kitchen?, and query preparatory, e.g., Can I borrow your notes?), and nonconvenionally indirect (strong and mild hints) (p.18). It has been found that there is a universal tendency for conventional indirect strategies to be preferred.

Since the CCSARP coding scheme was introduced, it has been widely adopted by scholars of Chinese requests. Zhang (1995) conducted a study of direct and indirect request strategies in Chinese in 12 scenarios with varying social variables. The results showed that Conventional Indirectness, realized mainly by zenmeyang 'how about' and neng 'can', was favored in most situations except when there was an asymmetrical power relationship between the speakers, when direct strategies were preferred. Social distance was also noted to affect speakers' choices. As the participants in most of the request contexts were friends or colleagues rather than intimates, conventional indirectness was the dominant choice (p.48). A study by Chen \& Tseng (2015), which analyzes Chinese textbooks in addition to DCT results, also demonstrates a similar preference pattern, with indirect strategies favored in both data types while polite expressions differed in these two data sources.

In addition to DCTs, Rue \& Zhang (2008) used role plays and natural conversations to investigate the effects of social distance and power in Chinese and Korean requests. Different from Zhang's (1995) and Chen \& Tseng's (2015) findings, both the Chinese and Korean subjects used more direct, straightforward strategies in natural settings than in role-plays. A similar tendency is observed by Jang (2014) in her study of requests in Taiwan Mandarin TV dramas. Yu (1999), a more comprehensive survey undertaken to explore the universalistic and culturespecific features of requests used by Chinese/English L1 and L2 speakers, also yielded similar findings about the higher frequency of direct strategies by Chinese L1 speakers, especially when $\mathrm{H}$ is of higher power. However, the direct strategies, mainly found in want statements, "combine both direct and indirect elements" (p.30o), e.g., I hope that you can let me take the exam on another day. Is that all right? (wo xiwang laoshi nin neng rang wo gaitian zai kaoshi, keyi ma?) (p.294). Overall, dominance is found to have greatest effect on the choice of request forms.

Despite the rich literature on requestive behaviors in Chinese, there remains a lack of studies on the realization patterns and subtypes of directive speech acts in TSM. In response to this gap, the current study investigates the subtypes of directives and their realization patterns. In the following discussion, we use the term 
"directives" to refer to directive speech acts and their subtypes. The term "request", employed as a general term in previous studies to cover all subtypes, is used in this study to refer only to one subtype of directives (Searle 1979:5). Specific definitions of directives and their subtypes are provided in Section 3.

\section{Directives: Definitions and subtypes}

\subsection{Directive speech acts}

Directives are defined by Searle (1979) as "attempts (of varying degrees) by a speaker or writer to get the addressee to do something" (p.11). They may be "modest attempts" that serve as invitations or suggestions. They may also be "fierce attempts" when the speaker insists that the addressee do something. In addition, the utterance must take place in an actual interaction between a speaker and the addressee (called "liveness" by K. Teng (2017)).

As a systematic account of the general rules of directives, Searle (1969) embraces the idea of "felicity conditions" of speech acts proposed by Austin (1962) and classifies the conditions of requests, the most common form of directive speech acts, in terms of their propositional content, preparatory preconditions, conditions on sincerity, and essential conditions, as detailed in Table 1 (Appendix II).

We can summarize the above conditions with four characteristics of directives (See also Wierzbicka 1991: 205, Stefanowitsch \& Gries 2003: 231-233):

a. The speaker's "desire" that the hearer perform the act,

b. The hearer's "ability" to perform the act,

c. The speaker's "power" over the hearer to perform the act, and

d. The hearer being under certain "obligation" to perform the act

Note, however, that these components vary depending on the force of the request. For example, an order has a stronger degree of imposition than a request because the former implies that the speaker has authority over the hearer. In this study, we will examine all manifestations of directives in TSM, as detailed in Section 3.2. ${ }^{1}$

1. Before we define the subtypes of directives, a distinction in terminology needs to be made between "directives" and "imperatives". Whereas "directives" is defined according to the illocutionary meaning it conveys, "imperatives" is a grammatical term referring to utterances/sentences that are grammatically marked with the imperative mood (Bybee 1995). In this study, we will use the term "directives" to refer to their different speech act subtypes in TSM, despite the fact that most of their realizations take the form of an imperative. 


\subsection{Subtypes}

All the directives count as an attempt for the speaker $(\mathrm{S})$ to get the hearer $(\mathrm{H})$ to perform a future action (A). Based on Searle $(1969,1979)$, Thornburg \& Panther (1997), Takahashi (2012), and Wierzbicka (1987), we further distinguish them into nine types: REQUEST, ORDER, URGE, BEGGING, WARNING, ADVICE, SUGGESTION, INVITATION, and OFFER. ${ }^{2}$

REQUEST is a typical directive in which $\mathrm{S}$ expresses his/her desire for $\mathrm{H}$ to perform A and believes that $\mathrm{H}$ is able to do it (Searle 1979:44, Takahashi 2012). By giving a REQUEST, the speaker (S) means that $\mathrm{s} /$ he does not want to say that the hearer $(\mathrm{H})$ has to do an action (A) but assumes that $\mathrm{S}$ has reason to say that $\mathrm{S}$ wants it to happen (Wierzbicka 1987: 51). In other words, it is neutral with respect to the power relationship between $\mathrm{S}$ and $\mathrm{H}$ and the degree of urgency or imposition. To distinguish this subtype of directive from the general word "request", a small capital REQUEST will be used throughout this study. The following instance illustrates this subtype:

(1) (To a friend)

Lí thèh khîlâi khò $a^{\mathrm{n}}$ tō chai.

you take up look then know

'You will know (its weight) if you lift (it).'

As for ORDER, in addition to the conditions that hold for a REQUEST, it has the "additional preparatory rule that $\mathrm{S}$ must be in a position of authority over $\mathrm{H}$ " and is "a decision that something is to be so" (Searle 1969:66). Therefore, the major distinction between ORDER and REQUEST lies in S's power over H. Failure to fulfill the desired act may result in unfavorable consequences for $\mathrm{H}$.

(2) (Master to servant) $)^{3}$

Lí khì iòhpâng kā goá théh tāmpóh tìnchīngê iòh lâi hōo góa, 2s go pharmacy KA $1 \mathrm{~s}$ take a.little tranquilizing medicine come Hoo $1 \mathrm{~s}$ sòa phâng chit poe chúi lâi.

then hold one cup water come

'Go to the pharmacy and get some tranquilizers for me. Then give me a glass of water.'

URGE is similar to REQUEST or ORDER. However, $S$ does not seek a benefit for himself and $\mathrm{S}$ has no power over the addressee. Above all, the action that $\mathrm{S}$ wants to cause $\mathrm{H}$ to do is one of immediate relevance and $\mathrm{S}$ is "trying to infect" the

2. A small capital will be used throughout the paper to refer to a given subtype of directives.

3. Abbreviations used in this paper are listed at the end of this article. 
addressee with his/her conviction" that it is necessary for $\mathrm{H}$ to do the action (Wierzbicka 1987:61-62). For example:

(3) (To a friend)

Kobiàt! Lí chhinsin lâi khòa ${ }^{\mathrm{n}}$ lah!

PN 2s in.person come look 3s UfP

'Ko-biat! Come look at him in person!'

Note that, in the above directives, $\mathrm{S}$ exerts a stronger force on $\mathrm{H}$ than usual to perform the desired action. These are regarded as prototypical imperatives by Takahashi (2012). In line with Taylor (1989:59), Takahashi (2012:76) treats the prototype as "an abstract representation of the conceptual core of a category". ORDER, REQUEST and URGE, can therefore be regarded as prototypical imperatives according to the following definition:

(4) Prototype of the English imperative

a. The speaker exerts a high degree of force in deictic setting toward the addressee, who will thereby perform an action in a hypothetical setting.

b. The speaker plays the semantic roles of Causer and Agent, and the individuated addressee plays the roles of Causee and Agent.

(Takahashi 2012:76)

BEGGING, is a non-prototypical imperative. While a fervent desire is expressed by $S$ for something beneficial to $S$ to happen, $S$ "feels helpless because he knows that he himself cannot cause [something] to happen", but it is $\mathrm{H}$ who can make it happen while he or she "evidently doesn't want to do it." Therefore, it suggests S's "humble, abject attitude", acknowledging "the potential giver's superior position" (Wierzbicka 1987:53). Therefore, with BEGGING, S recognizes H's power, minimizes the importance of S and maximizes that of $\mathrm{H}$ (Pérez Hernández \& Ruiz de Mendoza 2002: 265), e.g., (5):

(5) (A poor man is looking for a job in a factory.)

Siansin ${ }^{n}$ chíū hōo góa chiàh tō kàugiàh kiû lí hōo góa ù thâulōo kiû sir only let me eat then enough plead 2 s let $1 \mathrm{~s}$ have job plead lí khóliân góa.

2s pity $1 \mathrm{~s}$

'Sir, I would be content with a minimum to feed myself. Please give me a job; please have pity on me.'

WARNING is an utterance whereby $\mathrm{S}$ is telling $\mathrm{H}$ that a current state of affairs or a future event is not in H's interest and that $\mathrm{H}$ should do something about it. By giving a WARNING, $S$ has reason to believe a bad future event (E) will occur given the current situation or that there is an impending danger and that it is "not obvi- 
ous to both S and H that E will occur" (Searle 1979:28-29, 67). In (6), that there are many hypocrites is believed by $\mathrm{S}$ to have the potential to bring danger to $\mathrm{H}$ and therefore a warning is issued. WARNING can therefore be regarded as a special type of request when there is an associated danger looming before $\mathrm{H}$.

(6) (A Pharasee to a passersby)

Chitkú chin chē ké sianti chhián lín ài chù̀.

now really many false prophet please 2 s need.to pay.attention

'There are many hypocrites here. You need to take care. (Otherwise, they may find fault with you.)'

As with WARNING, ADVICE also tells H to perform A (Searle 1979:29), something that the addressee should do (Wierzbicka 1987:181). In ADVICE, $S$ expresses a situation that only benefits $\mathrm{H}$ and in fact is in H's best interests (Searle 1969:67). Furthermore, ADVICE imposes a strong obligation and high cost on $\mathrm{H}$ while there is little or no cost on S's part.

Suggestion invites $\mathrm{H}$ to imagine an action advised by $\mathrm{S}$ (Wierzbicka 1987:181). It differs from ADVICE in that the action is more tentative and there is a "high degree of optionality" and $\mathrm{H}$ "can choose freely whether to carry out the proposed action or not" (Pérez Hernandez \& Ruiz de Mendoza 2002:279). It also differs from ADVICE in that the former points to a non-moral act that does not necessarily entail a beneficial A to $\mathrm{H}$.

(7) (A woman is talking to his brother-in-law about her husband's condition.) Sióiâ chiàukhò $a^{\mathrm{n}}$ chitê chênghêng, lán tiòh chhián gōo ê sióiâ lóng brother seeing this condition 1PI have.to invite five CL brother all lâi chūchip tī lāuiâ $\operatorname{sinpin}^{\mathrm{n}}$ sūhāu i.

come gather at master side serve $3 \mathrm{~s}$

'Bro, given the current situation, let's gather all the five younger brothers together to look after the master.'

INViTATION is performed when $S$ uses an utterance to call H's attention to something pleasant that $\mathrm{S}$ wants $\mathrm{H}$ to do. It involves $\mathrm{A}$ that $\mathrm{S}$ believes would be good for $\mathrm{H}$ and conveys a polite attitude of $\mathrm{S}$, and little imposition is implied. In the play scripts, INVITATION tends to be used to show hospitality or is a proposal for a public event:

(8) (A host is inviting a guest to breakfast.)

Gâuchá chhián lâi $\quad \mathrm{sa}^{\mathrm{n}} \mathrm{kap}$ chiàh chátǹg good.morning please come together eat breakfast 'Good morning, come have breakfast together.' 
OfFER is closely related to ADVICE in that the former is also a kind of "altruistic" act. However, it differs from ADVICE in that OFFER involves some cost to S (Pérez Hernandez \& Ruiz de Mendoza 2002:266, fn. 6). It expresses S's desire that $\mathrm{H}$ would accept the offered object (cf. Wierzbicka 1987:190). Unlike INVITATION, OFFER involves an entity that is given away, whereas the former involves action toward S.

(9) (The host of a house is asking the guest to accept a gift.)

Chhián lí siu m̄bián khehkhì.

please $2 \mathrm{~s}$ accept no.need polite

'Please accept (the silverware); make yourself at home.'

The definitions of directives given above are used in this paper as the criteria for identifying subtypes of directives in TSM. Before the results are presented, we first describe the details of the methodology adopted for the analysis.

\section{Data, corpus, and coding}

The data are drawn from play scripts in the DADWT, ${ }^{4}$ which contains $2,580,000$ syllables of written TSM, including poetry, prose, fiction, and play scripts, divided into three periods according to the date of publication: Qing Dynasty (1885-1945), Japanese rule (1895-1945), and the post-war period (1945-). The play scripts comprise 49 episodes of moral/religious plays which originally appeared in newspapers published by the Taiwan Church Press (formerly Chü-Tin-Tông", i.e., "Treasure Hall"), ${ }^{5}$ containing 136,091 syllables, of which 33 were written by 11 identifiable authors, 13 by unidentifiable authors, and 3 by the editorial office. Four major themes can be identified: adapted Bible stories (BS), moral plays (MP), dialogues with personified animals (PA), and comic dialogues rich in rhyming lines (CM). To observe scripts that are closer to natural conversation, we excluded PA and CM from the search. Those texts with identical authors or topics, and those with an unknown year of publication were also excluded from the analysis. As a result, 20 play scripts were searched for directives, including ten BSs and ten MPs, a total of 59,380 syllables authored by ten different authors. Two of the 20 plays selected were published in the 1920s, seven in the 1950s, and eleven in the 1960 s (Appendix I).

Three rationales underlie our selection of play scripts in the corpus to search for directives. First, as argued by Toolan (1994: 2689), "many crucial structural

4. DADWT: http://ip194097.ntcu.edu.tw/nmtl/dadwt/pbk.asp

5. Taiwan Church Press: https://home.pctpress.org/?page_id=2319 
and functional principles are at work just as much in fictional dialogue as in natural conversation". In other words, such a register provides a useful database for a search of features that are present in natural conversation. Second, although natural conversation is most representative of language in use, a preliminary analysis of a spontaneous TSM corpus established by one of the authors indicates that directives are rare in conversation. In one 2-hour natural conversation $(5,612$ intonation units), for example, only one positive and one negative directive were found. This is mainly attributed to the subjective nature of spontaneous discourse, which abounds in stancetaking through expressions demonstrating subjectivity from a first person point of view, e.g., góa kā lí kóng 'Let me tell you' (Chang \& Hsieh 2017), or through narratives conveying speaker's negative appraisal of a non-present third party, e.g., complaining about a neighbor's greedy behavior. In such evaluative discourse, the addressee usually plays a listener's role. When the turn is taken over by the addressee, a new round of stancetaking by a current speaker, formerly the addressee ensues. Very rarely does a speaker attempt to ask the addressee to do something, since the requested action would entail discontinuity of the current topic and a change of scene. The result of the pilot analysis suggests that natural conversation may not always provide an optimal resource for directive research. The choice of drama scripts is further substantiated by the ubiquity of directives in the database. In the selected 20 play scripts, which contain 4,993 clauses and 59,380 syllables, a total of 408 directives were found. That is, on average, a directive occurs about every 10-11 clauses in the database. ${ }^{6}$ Put differently, there are 6,871 directives per million syllables, a frequency which clearly fulfills the 10-per-million-word criterion for a recurrent sequence as defined by Biber et al. (1999: 992). The above observations suggest that the play scripts constitute a useful source of directives.

The identification of the subtypes of speech acts was based on a thorough discussion between the two authors of the current study. Only after a consensus was reached was the coding of a given speech act finalized. With regard to the time of publication of the play scripts, our pilot analysis showed that although these texts were published in the early- to mid-2oth century, the directives are not different from those in current TSM. To confirm our initial judgement, we asked two native speakers of TSM who could also read written Taiwanese to evaluate the 408 directives. Both raters agreed that these directives are not different from those used in

6. A clause is defined as one that is separated by a Chinese punctuation mark, including ", ”, “。”, “?”, “!”, and “..." Basically, the unit corresponds to the boundary of a clause except in utterance initial address terms, e.g., Siansi ${ }^{n}$, i lâi a. 'Mister, here he comes.', which is considered as one single clause. 
contemporary Taiwanese. Therefore, we believe that the uses reflect the general use of these speech acts in current TSM. ${ }^{7}$

The following components of a directive proper were coded for the analysis. Note that, unlike Blum-Kulka, House \& Kasper (1989), who identify a request proper as composed of an alerter, a supportive move, and a head act, we do not include a supportive move as this alone does not constitute a directive.
a. Alerter
b. Discourse marker
c. Politeness marker
d. Subject
e. Modal expression
f. Verb phrase in the matrix clause
g. Utterance-final particle (UFP)
h. Question tag

An alerter is distinguished from a subject when there is an intonational break, indicated by a comma or an interjection marker such as ah between the alerter and the subject. A discourse marker is included in the analysis as it is within the scope of the directive when used. A politeness marker corresponds to the "explicit performative/hedged performative" strategy in CCSARP (e.g., I'm asking/I'd like you to move the car). It differs from a typical performative verb as Chinese usually employs a politeness marker/verb in a subjectless sentence to carry out the directive, e.g., [chhián $l i+\mathrm{V}]$. A modal expression, e.g., tióh 'have to' in TSM, functions similarly to the "obligation statement" in CCARRP (e.g., You'll have to move the car). In brief, ( $\mathrm{d}-\mathrm{f})$ together make up the head act of a directive. The UFPs and question tags, on the other hand, are included in the analysis as they are associated with stronger or weaker directive force. Example (10) illustrates the sequence of these components:

(10) Components and sequence of a directive speech act Alerter Polite marker Subj Modal Modifier VP UFP Q tag A-bêng chhián lí tiòh ài jīnchin thákchheh leh hó bô? PN please $2 \mathrm{~s}$ have.to industrious study UFP okay not 'Abieng, may you please study hard, okay?'

7. There was only one expression which one rater thought was different from the TSM use he knows about: chēche 'a lot'. However, according to one of the authors, the reduplicated chèche can be used in contemporary TSM expressions such as '(I'll) eat to my heart's content before leaving' (Chiáh hōo chēchè chiah lâi khì). 
A word of note is necessary before we report about the results and findings. Although the distinction between direct and indirect strategies has been focused on in L1/L2 pragmatics, it is surprising to find that indirect strategies, in terms of the CCSARP classification, account for only two percent of the directives in the play script corpus, realized as a statement or a question tag (e.g., lán nā bô tékpiát lâi sūhāu i bōesái tit 'We would be in trouble if we did not take special care to serve him'). Due to their low frequency, these indirect strategies are included as subtypes of directives according to the definitions presented in Section 3.2.

\section{Results}

As mentioned in Section 4, a total of 408 directives were found in the corpus. Eight subtypes can be identified, as indicated in Table 2 (Appendix II), in order of their prototypicality of directive force.

Ranking first is the prototypical directive, REQUEST, which is delivered when there is no special power or distance relationship that is attached to the requested act. The high frequency of ORDER, on the other hand, can be attributed to the roles more commonly found in the religious and moral plays, e.g., in master-to-servant talk. Similarly, Invitation, given by hosts to show hospitality and kindness are highly compatible with plays that promote moral values. The great incidence of BEGGING can be explained by the stereotypical roles in MPs, which usually portray beggars or poor people begging misers for money or food. In the following sections, each linguistic component is discussed in terms of their occurrence in the subtypes.

\subsection{Alerter}

Alerters are an important strategy in Chinese requests (e.g., Jang 2014:38-39), usually appearing at the beginning of an utterance to draw H's attention and to express S's intention to maintain or establish a "social relationship" (Zhang 1995:36). Consistent with previous research, most alerters are realized with an address term. ${ }^{8}$ However, unlike previous studies which found a high frequency of alerters (38\%-83\%) (Zhang 1995, Jang 2014, Chen \& Tseng 2015, and Geng 2015), they are infrequent in our corpus (11\%).

As suggested by Table 3 (Appendix II), alerters are more likely to be used in URGE, INVITATION, or SUgGestion, when $\mathrm{S}$ is eager to draw H's attention to the

8. All the 46 tokens of alerters in our corpus are realized by an address term except one, with the interjection $o e$. 
speech act that follows. In (11), the first name is used to call a friend to help dismiss a stranger who is trying to approach him:

(11) (To two friends)

Atāi, Tāipítāi, lâi! Pangchān góa kóan cháu i.

PN PN come help 1s push away 3s

'A-tāi, Tāi-pí-tāi, come! Help me get him away'.

First names can also be used between intimates or from a superordinate to a subordinate (Gu 1990, Wardhaugh 2006:268-269). In fact, they account for $34 \%(16 /$ 47) and are the most common address forms in the corpus:

(12) (A man to his girlfriend when he is about to go abroad to study)

Lēná, Che sī bōethang siámpī ê sūsit... Jînseng siôngsiông bōethang chiàu PN this is cannot avoid AC fact life often cannot follow lísióng lâi sengòah.

ideal come live

'Lena, this is something you cannot avoid...It's impossible to always live a life according to one's own will.'

(13) (Master to servant)

Sūnsìn ah, lí tiỏh koh ke chúnpī chitêlâng hūn.

PN UFP 2s have.to again add prepare one person share

'Sunsin, you have to prepare one more person's share.'

When addressing someone with greater power or of higher status, e.g., in BEGGING, $\mathrm{S}$ is asking $\mathrm{H}$ a great favor or to show politeness, hospitality or solidarity. Address terms like this include kinship terms or titles, which usually co-occur with a politeness marker chhián 'please':

(14) (A woman begging her husband's younger brother to lend her some money) Sa $^{n}$ chek à, chhián lí lâi khui lí ê chûsim, hōo góan m̄bián uncle UFP please $2 \mathrm{~s}$ come open $2 \mathrm{~s}$ AC kindness let $1 \mathrm{P}$ avoid hāmlòh tī chóatkéng sílōo.

fall.into at abyss dead.end

'Uncle, please have mercy (on me) because of your big brother so that we won't fall into a hopeless state.'

As discussed above, alerters are mainly used to address an acquaintance to call his/her attention to something of immediate relevance (UG) to indicate S's polite attitude (IV or BG). Although they are not obligatory in a directive, they serve as an expressive medium to yield a more effective speech act. 


\subsection{Discourse marker}

After the alerter, a discourse marker may be used to indicate S's stance or denote the logical relation between the current utterance and the previous turn. Similar to the case of alerters, a discourse connective is not common, accounting for only $10 \%$ of the total of directives.

As indicated in Table 4 (Appendix II), the utterance-initial $t a^{n}$ accounts for a substantial portion of the discourse markers (33/48). According to X. Chen (1991:1724), $t a^{n}$ indicates a current situation that is undesirable, e.g., $T a^{n} h \bar{a} i a$ (now-bad-ufP) '(We're) in trouble now. or $T a^{n} \bar{u} c h \hat{\imath}^{n} b \hat{o}$ ? (Now-have-money-not) 'Do you have money or not?'. It also resembles the English adverbial now, which, in addition to serving as a time adverbial, encodes a procedural meaning and "frames" the following utterance (McCarthy 1991:13-14) "in which now occurs as communicating something that is in part continuous with what is already in view but also in some way distinct" (Schourup 2011:2117) and "that contrasts with already communicated information" (p.212o). In the directives in our corpus, $t a^{n}$ functions similarly to the English utterance-initial now. It does not necessarily preface an undesirable situation but introduces a directive which moves the conversational topic forward by highlighting the relevance of the current proposition and to direct the addressee to carry out a requested action. It occurs in almost all the subtypes, though all with relatively low frequency: ${ }^{9}$

(15) (A miser woke up from a nightmare and felt relieved to see it was a construction worker not the god of death standing in front of him.)

Oh, lí sī saihū tiòh bô, lí lâi chin túhó! Kámsiā siōngtè,

oh 2 s be maestro right not 2 s come really coincidental thank God

hókachài lí ū lâi chia, nā bô góa chitmiā kán tiòh oohooaichài, ta ${ }^{n}$ lucky 2s ASP come here if not $1 \mathrm{~s}$ now dare would die now chhiân lí kā góa thin chit poe léng chúi lâi hōo góa.

please 2s KA 1s pour one CL cold water come give 1s

'Maestro, is that you? What a relief. Thank God! How lucky I am to have you here. Otherwise, I would be taken away by the god of death. Now please give me a cup of water.'

9. Although WARNING involves a desired act which is urgent, the non-occurrence of $t a^{n}$ in WARNING may be due to the low frequency of this type of directive. More instances of WARNING are needed in future research to explore its correlation with $t a^{n}$. 
(16) (A wife is talking to her husband after he is back from helping some kids.) Sī, i hiah ê gínná chin koai, koh chin phahpiàn, ánni chin hó, (RQ) yes $3 \mathrm{~s}$ there AC child really good and really hard.working thus very good ta $^{\text {n }}$ kóankín khì séèk, siochúi íkeng sio lah.

now hurry go wash hot.water already hot UFP

'Yes, the children there are really good and hard-working. Good, now, go and take a shower. Some hot water is ready'.

The other discourse elements include expressions in the form of a semantically weak lexical bundle composed of a first person subject and an evidential verb (goá khòa ${ }^{n}$ 'I see') or an epistemic verb (goá sīün 'I think') (cf. Kärkkainen 2003), a sequential marker (soah 'then' and tèit hoan 'first'), an attitudinal marker (e.g., soahbēhiáu 'How do you not know') (Chang 2015), or a consequential marker (e.g., sóoyí 'so'). As indicated in Table 4 (Appendix II), these markers are most frequent in suggestion, which might be due to the mild tone they convey. Extract (17) is an illustrative example:

(17) (Wife to husband, suggesting that their maid and her son stay overnight with them)

Góa siūn êàm tiòh kiò Málī kap i ê kián, chhōa lâi chia khùn

1s think tonight have.to ask PN and 3s AC son bring come here sleep

khah anchôan.

more safe

'I was thinking that it might be safer for Mary and her son to come over and sleep here tonight.'

Generally speaking, the discourse marker $t a^{n}$ is used in most directive subtypes, used to encode the relevance of the situation or S's hope that A be performed, a feature closely related to the nature of a directive. By contrast, logical markers are less pertinent to S's intent, as they denote inter-sentential propositional relationships.

\subsection{Politeness marker}

A politeness marker may be used after the discourse marker to strengthen S's sincerity for a given act to be performed. Of the 408 tokens, 120 (29\%) contain a politeness marker, $90 \%$ of which are composed of the honorific form chhián 'please' (Table 5, Appendix II).

The distribution of chhián is more pronounced when the directive underscores the importance of $\mathrm{H}$ and S's eagerness for the action to be performed, such as in BEgGING, INVITATION, OFFER, REQUEST and sUgGESTION. For example, in 
BEGGING, in particular, $\mathrm{S}$ is in a disadvantageous position and is fervently asking someone who has the ability to carry out a desired act. The addition of a marker of politeness may make $\mathrm{H}$ more willing to carry out the act. In the cases of INVITATION and OFFER, chhián is more inclined to take the formula [chhián chē] 'please

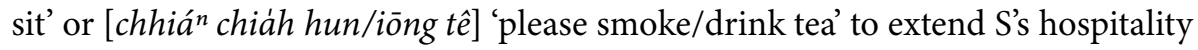
when $\mathrm{H}$ visits:

(18) (A beggar to a rich man)

Góa sī chitê pichhám kàukèk sìbīn chóatlōo ê khitchiảh, chhián lí $1 \mathrm{~s}$ be one pathetic extremely four.side dead.end AC beggar please $2 \mathrm{~s}$ lînbín lâi siásì góa!

pity come give $1 \mathrm{~s}$

'I'm a tragic, destitute beggar. Please have mercy and give (some food) to me.'

(19) (Host to guest)

Lâu siansi ${ }^{\mathrm{n}}$ chhián ${ }^{\mathrm{n}}$ chia chē.

PN mister please here sit

'Mr. Liu, please be seated here.'

The other politeness markers mainly take the form of a performative verb, used by S to explicitly express hope ńgbanng 'to hope' or to beg H earnestly for a huge favor páithok/kiû 'to plead' (cf. Jang 2014:69), the former being prevalent in ADVICE and the latter in BEGGING:

(20) (Principal to a student who was just enrolled in the school)

Hoangêng lí thákchheh, ǹgbāng lí phahpiàn thảk, chionglâi ittēng $\bar{e}$ chòe welcome 2 s study hope 2 s work.hard study future surely will be chitê gâulâng.

one capable.man

'Welcome (to our school). I hope that you can study hard, and you will surely be a successful person in the future.'

(21) (Servant to master)

Góa ê chúlâng ah, kiû lí lînbín góa chitê pibîê thângthōa!

1s AC master UFP plead 2s pity $1 \mathrm{~s}$ this worthless worm

'My master! Please have pity on me, a worthless worm.'

Divergent results have been observed in the use of optative/want statements in requests in earlier studies. Yu (1999:294), drawing data from DCTs, argues that hope is often used by speakers when addressing someone of higher social status, e.g., Wǒ xīwàng nín néng ràng wǒ găitiān zài kăo shì, kě y̌̀ ma? 'I hope that you can let me take the exam on another day, is that all right?'. Chen \& Tseng (2015:135) note a reverse trend, as only $10 \%$ of the speakers use xîwàng when addressing a teacher, one of a higher social status. Comparatively, we have not found cases 
where $\mathrm{S}$ addresses a dominant $\mathrm{H}$ with a hope statement. This might be due to a cross-dialectal difference between Mandarin and TSM or because of the type of data used for analysis.

Simply put, the predominant politeness marker is chhián, which is more inclined to take an overt subject to form a bundle. Though not obligatory, it is preferred when $\mathrm{S}$ shows respect for $\mathrm{H}$ and expresses a strong desire for an intended action to be carried out, as in BEGGING, REQUEST, and SUGGESTION, or when $S$ is receiving a guest with a friendly welcome, as in OFFER and INVITATION.

\subsection{Subject}

The subject refers to the agent of the action requested. An overt subject can be found in about half of the directive instances $(53.9 \%, 220 / 408)$ (see Table 6 , Appendix II), which is consistent with the findings of Zhang (1995) and K. Teng (2017).

Overt subjects can be classified into three major types: H-dominance (e.g., lí 'you' (sg.), lín 'you' (pl.), S-dominance (e.g., gòa 'I'), or S\&H-dominance (lán '(inclusive) we') (Kohnen 2008) (see Table 7, Appendix II). Most of the subjects take an $\mathrm{H}$ perspective (lí or lín), agreeing with the general tendency reported in the literature (e.g., Blum-Kulka, House \& Kasper 1989, Zhang 1995, Lin 2009). Ranking second on the subject type is the H\&S-dominated, first person plural (inclusive) lán, used to signify S's respect (Brown \& Levinson 1987:180, 200).

In concert with its mitigating tone, as can be seen in Table 7 (Appendix II), lán occurs in directives with an affiliative attitude and displays a tentativeness regarding the requested action: ADVICE, INVITATION, OFFER, and SUGGESTION. Examples of these subject types are given below:

(22) (Host to a visitor) (H-dominance)

Chhián lí mịbián khòalū chò lí ansim tòa, ta ${ }^{\mathrm{n}}$ hia chē. Àmtǹg liâmpi ${ }^{\mathrm{n}}$ please 2 s no.need worry do 2 s relaxed stay now there sit dinner soon è pīpān hó.

will prepare well

'Please do not worry and stay overnight with us. Now be seated there. Dinner will be ready soon.'

(23) (A blind man telling the hearers to look at his healed eyes.) (H-dominance) M̄sī, m̄sī, kinájit ê góa sī móa ù ǹgbāng ê, chhián lín khòan góaê (RQ) no no today AC 1s be full have hope NOM please 2P look $1 \mathrm{~s}$ bákchiu leh.

eyeball UFP

'No, no. Now I'm a person full of hope. Please look at my eyes. (I'm healed.)' 
(24) (A man to his girlfriend) (S\&H-dominance)

Che sī bōethang siámpī ê sūsit. Lán tiỏh līkhui. Jînseng siôngsiông

this is cannot avoid AC fact $\mathbf{1 P}$ have.to leave life often

bōethang chiàu lísióng lâi sengòah.

cannot follow ideal come live

'This is something you cannot avoid. We have to leave. It's impossible to always live a life at one's own will.'

Note that in (24), no UFP is attached to the utterance, while a corresponding expression in Mandarin would require a UFP $b a$ to mitigate the directive force, e.g., Lán tióh likkhui in Mandarin Chinese is zanman/women likai ba 'Let's go' This suggests that UFPs may not play an equally important role in directives across different Chinese dialects. As will be shown in the following discussion, UFPs occur in less than 10\% of directives in the corpus (See Section 5.6.2 for details).

The other types of subjects, in particular, tákke and kokū 'everybody', which indicate S's politeness, are exclusively used in INVITATION, a polite speech act in which $\mathrm{S}$ asks $\mathrm{H}$ to take part in a joint, pleasant activity, as in (25):

(25) (Priest to people in the neighborhood)

Ía chhián kokūi siôngsiông kàu góaê sió lépàitn̂g lâi thia ${ }^{n}$

Later please everybody frequently come 1s little church come listen hokim.

gospel

'Dear all, from now on, please come to my small church to listen to the gospel whenever you can'.

The omission of subjects may be accounted for by the meaning inherent in the directive subtypes. In the cases of ORDER and URGE, the subject omission can be attributed to the immediacy of the action required, as a shorter utterance registers an emphatic effect. The absence of the subject in INVITATION, on the other hand, is related to the type of co-occurring verb. In INVITATION, there is an extraordinarily high number of the verbs lâi and lâikhì (90\%), both of which are addressee-oriented and allow for a regular omission of the agent except in the formula [lán lâi] or [lán lâikhi] 'let's go'. Examples (26) and (27) illustrate zerosubject directives:

(26) (Head of bandits ordering his subordinate to answer his question) Sī símmih lâng? Khah kín kóng!

be what man more hurry say

'Who's knocking at the door? Hurry and tell me (who it is)!' 
(27) (A man is taking his friend's hand)

Lâi! Lâi! Lâi khòa ${ }^{\mathrm{n}}$ Bísàia lah.

come come come look Messiah ufP

'Come! Come! Come and see the Messiah!'

Overall, the most widely used subjects are $\mathrm{H}$-dominated, whereas $\mathrm{S} \& \mathrm{H}$ dominated subjects occur in more casual and relaxing settings. These findings largely mirror those of previous studies on the distribution of subjects in Mandarin Chinese. Directives with zero subjects, on the other hand, tend to take an addressee-oriented verb lâi 'come, hither', indicative of a casual tone, e.g., in INVITATION, or words such as kin 'hurry' to mark urgent matters.

\subsection{Modal verb}

A modal verb may follow the subject. On average, approximately one out of every five directives takes a modal auxiliary $(85,21 \%)$ (Table 8 , Appendix II). Modals in directives fall into the category of deontic modality (Bybee 1995:4, Nuyts, Byloo \& Diepeveen 2010:27), manifesting H's obligation or necessity (Bybee 1995:4), including tióh 'have to, need to', tióhài 'need to', ièngkai 'should', and êthang 'may, with tióh constituting a remarkable proportion (77/87, 89\%) (see also K. Teng 2017 for a similar observation), especially in directives involving deontic modality such as ADVICE and WARNING. By contrast, INVITATION, which focuses on the "conditional wanting" of $\mathrm{S}$ when an invitation is given and the free will of $\mathrm{H}$ to decline it (Wierzbicka 1987:82), is lacking in such modal verbs. A number of excerpts discussed above ((13), (17) and (24)) have demonstrated this marked density of tióh.

In addition to acting as a stand-alone modal, tióh also forms a bundle with the adverb $m \bar{a}$ 'also' or its variant $i \bar{a}$ 'also', or the auxiliary ài 'need to' or ingtong 'should' to strengthen the deontic meaning. Among them, mā tióh is loaded with a strong opposition stance toward a given conduct by $\mathrm{H}$ :

(28) (A friend encouraging communication between a mother and the daughter) Góa khò ${ }^{\mathrm{n}}$ lín nn̄g lâng long tiòh ēng léngchēngê thâunáu lâi $1 s$ see 2P two people all have.to use calm brain come chhúlí tāichì... iā tiòh ēng chhamsiông ê thàitō; kóng kàu píchhú handle thing also have.to use discussion AC attitude talk until each.other e "hōosiong liáukái".

will each.other understand

'I feel that you have to handle this problem with a cool mind... you need to negotiate until you understand each other's perspective.' 
(29) (Servant to master)

Thâuke ah... lán ê sìnmiā kójiân bô gōakú, lán mā tiòh sí hōo lâng master UFP 1PI AC life really not long 1PI also have.to die Hoo people iúsóo thang siàuliām lán, m̄thang sí hōo lâng hoanhí phahchhiú. have be.able.to remember 1PI do.not die Hoo people happy applaud 'Sir, ...our life is short, and we have to let people remember (our good deeds) after we die. Do not let people applaud our death.'

\subsection{Verb}

The verb(s) is the crucial part of a directive indexing the desired action. The action can be realized by either a single verb or a complex verb construction. Based on Levin (1993), Traugott (1991), Kohnen (2008) and Takahashi (2012), these verbs are classified into 11 types according to their semantic functions: dynamic verbs, stative verbs, and verbs describing different body functions. The occurrences of single verbs are discussed first.

\subsubsection{Single verb}

Single verbs constitute the majority of directive verbs $(311 / 408,76 \%)$. Table 9 (Appendix II) shows that they are primarily realized by dynamic verbs, including displacement and directional verbs, followed by stative verbs (15\%) and uttering verbs (14\%). The distribution of these verbs largely mirrors Traugott's (1991:392ff) findings about the semantic areas of speech act verbs (spatial, uttering, mental/ psychological, and vision).

Displacement verbs are used to denote actions that involve the spatial displacement of H's actions. Verbs of this type include phâng 'to hold on hand', tāngchhhiú 'to start action', thîn 'to pour (water)', théh 'to take', thoa 'to drag', khìg 'to place', kiân 'to walk', tah 'to paste', chhoā 'to bring', chèng 'to plant', lîkhui 'to leave', cháu 'to run/flee', chhōe 'to look for', kàu 'to arrive', and chhiün 'to draw up (water)'. Displacement verbs are ubiquitous except in WARNING. Excerpts (30)-(31) are cases in point:

(30) (Bandit to two people at the door)

Lín nn̄g lâng beh chòe símmih? Chiong línê búkhì khǹg leh, chìnchêng $2 \mathrm{P}$ two people want do what CHIONG $2 \mathrm{P}$ weapon place ASP advance lâi kóng tiâukiān .

come talk condition

'What are you doing here? Put your weapon there and come in to negotiate conditions.' 
(31) (A woman is inviting a stranger to draw water from a well.)

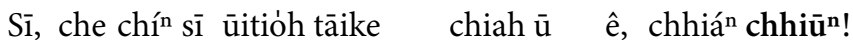
yes this well be for everyone then exist AC please draw 'Yes, the well was built for everyone. Please feel free to draw (water).'

An important feature that distinguishes TSM from Mandarin and English directives is the use of directional verbs, composed predominantly of lâi 'come' and khi 'go'. Like displacement verbs, directional verbs are pervasive in most directive subtypes except in WARNING and are used by $\mathrm{S}$ to invite $\mathrm{H}$ to a pleasant event, to order $\mathrm{H}$ to move away from $\mathrm{S}$, as an offer for something desirable, or to urge $\mathrm{H}$ to take an immediate action. The different intentions of $S$ are reflected in the directions encoded by the verbs. Verbs denoting movement "away" from S (khi) are usually found in directives such as ORDER, whereas those denoting actions "toward" $S$ (lâi and the compound lâikhi) are more common in INVITATION, OFFER, BEGGING, and SUGGESTION. The respective distribution of the two types of verbs in actions with positive and negative affect concurs with Lee Chen's argument (1997:107) that lâi is correlated with a gentle, suggestive mood whereas khì implies an adversative mood. The most prevailing occurrence of lâi is found in INviTATION, realized in English by let's (Takahashi 2012: 23), whereas khì and khui 'away' and verbs characterizing actions away from $S$ predominate in ADVICE, ORDER, REQUEST and URGE, as in the following examples:

(32) (To a friend)

Lán lâikhì.

1PI come

'Let's go.'

(33) (An old man is urging a child to go home soon.)

Lí tiòh kínkín tńgkhì m̄thang khì pàtūi thitthô, tiòh khah siósim

2 s have.to hurry return do.not go elsewhere play have.to more careful leh!

UFP

'You have to go home soon. Do not hang out. You need to be more careful.'

Mental verbs describe activities that have no obvious spatial displacement of the participants but involve mental processes or changes in cognitive states. They are mainly composed of verbs such as boēki 'to forget', khóliân 'to pity', pótiōng 'to take care', sinkhò 'to trust', ióngkám 'to be brave', oànhūn 'to hate', kianchhî 'to insist', tàiliām 'to remember', siün 'to think', chunsiú 'to follow (rules)', hoan hí 'to rejoice,' hiángsiū 'to enjoy', siósim/chùì/thêhông/sèjī 'to caution; to be careful', kàmtok 'to supervise', and kinsin 'to be cautious. They are more frequently used in ADVICE, BEGGING, ORDER, REQUEST, and WARNING, most of which refer to a given state of 
mind that $\mathrm{S}$ intends $\mathrm{H}$ to maintain so as to invite a favorable outcome or to avoid a serious consequence of a given action.

(34) (Rich man to servant)

Thòeāu! Lí tiòh kínsīn lí ê sóo chòe, nā bô tekkhak beh tiàusílí tī step.back 2 s have.to be.careful $2 \mathrm{~s}$ AC all do if not surely will hang $2 \mathrm{~s}$ at chhiūténg!

treetop

'Bug off! You have to be careful about everything you do. Otherwise you will be hanged on a tree until you are dead!'

(35) (A woman is asking a stranger to stay away from her.)

Tiāmtiām! Kiân khui khì hó $\overline{\mathrm{m}}$ ?

quiet go away go okay UFP

'Shut up! Stay away from me, okay?'

Uttering verbs such as "utter", "speak", "call", and "shout" are an essential speech act verb type in the history of English (Traugott 1991:390, 392). In our corpus, we also observed a similar pattern. Almost as frequent $(14 \%, 56 / 408)$ as stative verbs, uttering verbs focus on H's vocalized actions for fulfilling an interactional need, e.g., chhián 'to invite', hoanék 'to translate', kóng 'say; talk', tahéng 'promise', chúi 'to give ideas', chhiùn 'to sing', and iánsoat 'to give a speech'. Despite the lack of movement in H's actions, these verbs convey processes (e.g., hoanék or chhiù ${ }^{n}$ ) or changes of state (e.g., tahèng) and are more closely related to ADVICE, REQUEST, SUGGESTION, and URGE in single verbs: ${ }^{10}$

(36) (A matchmaker urging a woman to agree to a rich man's proposal)

I sī teh chòesenglíêlâng, ùsiá kap lâng tāmpóh èngsiû; lim

3s be Asp business.man sometimes with people a.little socializing drink kóa chiú... che $\overline{\mathrm{u}}$ sián iàukín? Góa khòa ${ }^{\mathrm{n}}$ lí tiòh sûisî tahìng i a.little wine this have what matter $1 \mathrm{~s}$ see $2 \mathrm{~s}$ have.to anytime promise $3 \mathrm{~s}$ khah hó, inūi kihōe nā sitlòh chiū bēthang koh tittióh lah. more good because opportunity if lose then not.able.to again get UFP ' $\mathrm{He}$ is a businessman, so it is natural for him to socialize and drink a little...I feel that you should accept (his proposal) as soon as possible, because otherwise you might never have the chance again.'

10. However, uttering verbs are used in Invitation in complex verb constructions in the pattern [lai $\mathrm{V}]$. 
(37) (School president inviting an outstanding alumnus to give a speech)

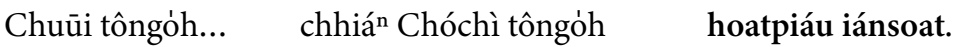
every fellow.student invite PN fellow.student present speech 'Dear all...(let's) invite (our outstanding alumnus) Chochi to give a speech.'

A benefactive verb takes a beneficiary as its object, including hoo 'to give', pangchàn 'to help', chítō 'to guide', siu 'to put away', kiù 'to save', hîu 'to help (get up)', chhōa 'to take (someone)', pun 'to share', sisiá 'to give to charity', chù 'to inject', siàbián 'to forgive', chioh 'to lend', chhiàn 'to hire'. Such verbs are used as main predicative verbs with hoo additionally functioning as a disposal marker in the [hōo (NP) V] construction (see Section 5.7.2).

As shown in Table 9, a beneficiary-marking verb, when acting as a standalone verb in a directive, mainly appears in BEGGING and REQUEST. Such verbs usually maximize H's power to fulfill a desired action for the benefit of S, e.g., (38). In the other directives, the beneficiary may be $\mathrm{H}$ or a third party, e.g., (39):

(38) (A beggar to a rich man)

Góa sī chitê pichhám kàukèk sìbīn chóatlōo ê khitchiảh, chhián lí

$1 \mathrm{~s}$ be one pathetic extremely four.side dead.end Ac beggar please $2 \mathrm{~s}$ lînbín lâi siásì góa!

pity come give $1 \mathrm{~s}$

'I'm a tragic, destitute beggar. Please have mercy and give me (some food).'

(39) (Suggesting that his friend forgive a servant who fled and returned)

$(\mathrm{AD})$

Siatsú Onîsebóo nā hóekái, lán iûgôan tiòh siàbián i.

if $\quad$ PN if repent 1PI still have.to forgive $3 \mathrm{~s}$

'If Onisebo is willing to repent, we have to forgive him.'

Ingesting verbs, or verbs of consumption, are found almost exclusively in OFFER, where $S$ expresses his/her hospitality toward a visitor by offering food, drinks, or cigarettes.

(40) (To a guest)

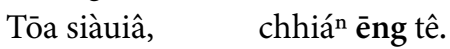

big junior.master please use tea

'Big master, please enjoy your tea.'

(41) (An old man comforting a child)

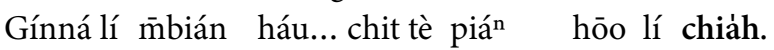

child 2s no.need cry this CL pancake Hoo $2 \mathrm{~s}$ eat

'Child, don't cry. Eat this pancake.'

Verbs of vision, including $k h o ̀ a^{n}\left(k \iota^{n}\right)$ 'to see', figure as a major recurring verb type in directives. When used as single verbs, they only occur in REQUest and always 
take either the politeness marker chhián, or an overt subject, or both to form a polysyllabic bundle, since the utterance would sound unnatural if it only contained a monosyllabic verb (see K. Lee 1976 for the inclination of Chinese to be polysyllabic). It will also be shown in Section 5.8.2 that verbs of vision are prone to co-occur with a directional verb lâi.

(42) (A young man to his friend)

Eh! Lí khò $\mathrm{a}^{\mathrm{n}}$, hia $\overline{\mathrm{u}}$ chit pau míh, $\overline{\mathrm{m}}$ chai sī símmih, lán lâi khò ${ }^{\mathrm{n}}$. INTJ $2 \mathrm{~s}$ look there exist one CL thing not know be what 1PI come look 'Eh! Look, there is a package. I wonder what it is. Let's take a look'

\subsubsection{Complex verb construction}

About one-fourth of the directives (97/408) take a complex verb construction to denote the desired action. One particular feature that distinguishes TSM from other languages is the considerable proportion of directional complements $(83 \%$, $81 / 97)$ in these constructions. As discussed above, directional verbs constitute a preferred pattern of directives in TSM (see Section 5.6.1). Second to the directional component is a disposal construction marking an NP with a variety of semantic roles. Other benefactive verbs comprise the remainding directives with complex verbs. Table 10 (Appendix II) presents the distribution of these verb patterns in different subtypes, and a list of the major co-verbs in these constructions is given in (43):

(43) Recurrent co-verbs in complex verb constructions in directives

a. Directional

b. Disposal constructions:

i. $k \bar{a}$-construction, with $k \bar{a}$ marking either a beneficiary, goal or source role

ii. hōo-construction, with hōo marking either a beneficiary or object NP

iii. chiong-construction, with chiong taking a preposed object

c. Benefactive constructions.

Directional complements, typical of which are lâi 'hither', khì 'thither', and lâikhì 'hither', are used in complex verb constructions to indicate the intended action of moving toward or away from the speaker. As in the distribution of directives with single verbs, lâi and lâikhì are favored in actions that denote a mild, positively evaluated mood, as in (44) and (45), whereas khi and other verbs indicating actions away from $S$ are preferred for actions that express urgency, as in (45), or adversity, as in (46): 
(44) (The host invites a student from Germany to perform on stage.)

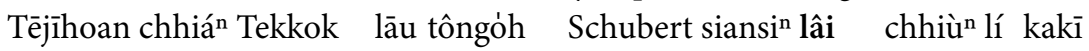
second please Germany old classmate PN mister come sing 2 s self chòe $\hat{e}$ sèkài bêng khek. create AC world famous song 'Next, our old classmate from Germany, Schubert, please come and sing (for us) a world famous song that you wrote yourself.'

(45) (Doctor to nurse)

Bíiông sióchiá, lâi hùisîn lí khì chhián hitê bē tōabèh môai ê lāuapeh PN miss come bother $2 \mathrm{~s}$ go invite that sell barley porridge AC old.man lâi chitē hó bô? come a.little okay not

'Miss Biiong, please go and ask the barley porridge vendor to come, would you?'

(46) (Master to Servant Khekliàtkhek)

Khekliàtkhek, lí tòtńg khì chòe lí kakî ê kang, mōbián chhap chitê tāichì. PN $2 s$ return go do $2 s$ self AC work no.need mind this matter 'Clark, go back and do your own work. Don't mind the business here.'

In (44), lâi is used to politely invite a guest to sing a song on stage. As for (45), a direct translation of the utterance would be 'Miss Biiong, please bother to come and go asking the old barley porridge vendor to come, would you?', which sounds odd and redundant. In this example, we observe a bleaching of the verb lâi, which together with hùisîn 'to bother; take one's time' forms a formulaic expression to express S's politeness toward H. In fact, lâihùisîn is used recurrently in TSM as a preface to minimize the imposition of a request, e.g., Siansin ${ }^{n}$, hùisîn lí kā goá chittiám chítō, hó bô? (sir-bother-you-give-me-a little-guidance-alrightnot) 'Sir, please take time to give me some guidance, okay?' The complement khi, by contrast, usually takes a post-verb position to denote the direction iconic of the requested action. It conveys an additional distancing tone on the part of the speaker. The two directional complements function complementarily to signify S's stance toward the directed act.

The $k \bar{a}$-construction, on the other hand, is a versatile pre-verbal morpheme marking an NP as a beneficiary, maleficiary, goal or source interwoven with the action denoted by the associated VP, with the construction $[k \bar{a}$ (NP) V] (S. Teng 1982, Huang 2015). Eighteen $k \bar{a}$-instances are in the corpus, suggesting that it is a recurrent pattern in directives, especially in those that carry a stronger directive force, especially ORDER (65\%) and REQUEST (20\%). The thematic role of the complement NP includes a beneficiary, maleficiary, source, or goal: 
(47) (Carpenter to miser, about the construction fee the miser promised to pay) Thâuke ah, góa chaiián lí ê lâng chin khiáu koh chiàmpângî, sóoí (RQ) master UFP 1s know 2s AC person very smart and take.advantage so ēng kóng ê bōe ansim, chhián lí tiòh kā góa siá tī chóa siōng. use say NOM not secure please $2 \mathrm{~s}$ have.to KA $1 \mathrm{~s}$ write at paper up 'Sir, I know you are cunning and like to take advantage of others, so (I feel) insecure simply with a verbal agreement. Please write (the amount you promised to pay) down for me on the paper.'

(48) (The speaker asks his friends for help.)

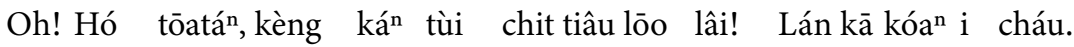
INTJ really bold should dare from this CL road come 1PI KA push 3s away 'Oh! How dare (he) take this route! Let's drive him away'

There is also a special use of $k \bar{a}$ that behaves like the so-called "unselected warning construction (UWC)", which expresses "negative emotion on the part of the speaker" (Huang 2015: 66), where the complement NP of $k \bar{a}$ does not have a specific thematic role but alludes to S's negative appraisal. The stance-marking $k \bar{a}$ can also co-occur with a formulaic, semantically void bundle $k \bar{a}$ góa (literally 'giveme') or lí chò lí kā góa ('you-do-you-give-me') to strengthen the directive force:

(49) (To a stranger)

Lí kā góa cháukhui!

2s KA 1s walk.away

'You, go away.'

(50) (Miser to a construction worker)

(OD)

Saihū ah, lí chò lí kā góa khí, m̄bián koh khòalū itchhèêsū.

master 2s 2s do 2s KA 1s build no.need again worry everything

'Maestro, you go ahead and build (the barn). Do not worry about anything anymore'.

The third complex verb construction contains the disposal marker hōo. According to H. Lee (2009), hōo occurs in ditransitive or resultative constructions (RC). The ditransitive can be further distinguished by its dative and purposive uses, and the $\mathrm{RC}$ tends to be atelic, realized by an adjective or a clause: 
(51) Types of hōo:

a. Dative: [S V OD hōo OI]

Asam sàng chit pún chheh hōo Abí.

PN give one CL book HOO PN

'Asam gave a book to Abi.'

b. Purposive: [S V OD hōo OI V $\mathrm{O}_{2}$ ]

Asam sàng chit pún chheh hōo Abí khoann.

PN give one CL book HOO PN read

'Asam gave a book for Abí to read.'

c. Resultative: [[S $(k \bar{a}) \mathrm{O}_{\mathrm{D}} \mathrm{V}$-hōo $\left.\left.\mathrm{RC}\right] \mathrm{V}-h \bar{o} o \mathrm{RC}\right]$

Góa seng kā ōe kóng hōo chhingchhó oh.

$1 \mathrm{~s}$ first KA word say HOo clear UFP

'I say the words first and make them clear.'

In the directives in our corpus, hōo is also preferred in BEGGING, ORDER, and REQUEST. They occur in situations when $S$ is eager for the requested action to be carried out, as exemplified in (52)-(56). Note that hoo in (54) co-occurs with chiong, the fourth recurrent marker in directives. Similar to the case of $k a$ and hoo, chiong is used in directives where $\mathrm{S}$ expresses his/her intent in a straightforward or determined tone, e.g., (55), where the mother is telling the bandit with strong determination that she doesn't want herself and her son to be torn apart. In (56), on the other hand, two formulaic sequences co-occur in one turn: the derogatory comment lí chin gōng 'You are so stupid' and the comment sòah bōe hiáutit 'How (do you) not know' with the counter-expectation marker soah (Chang 2015). These lexical chunks are used to demonstrate S's extreme irritation and contempt for $\mathrm{H}$.

(52) (Old woman to a rich man)

Góa ê pichhám chíu lí èthang kā góa káikoat... Chhián lí ê chîn ${ }^{\mathrm{n}}$ pun 1s AC misery only $2 \mathrm{~s}$ can $\mathrm{KA} 1 \mathrm{~s}$ solve please $2 \mathrm{~s}$ AC money give hōo góa!

\section{HOO 1s}

'Yes, only you can solve my miserable situation. Your money will grow fungus and rust if you do not have pity on me. Please give me some of your money'.

(53) (Master to servant)

Lí khì iỏhpâng kā góa thẻh tāmpóh tìnchīng ê iòh lâi hōo góa. 2s go pharmacy KA 1s take a.little tranquilizer AC medicine come Hoo 1s 'Go to the pharmacy and get some tranquilizers for me.' 
(54) (A farming expert talking to peasants)

Lín khì chiong hn̂g lê hōo chhengkhì, āulâi chèng hanchû.

2P go CHIONG field plow Hoo clean later grow sweet.potato

'(Now) you go to plow the field and grow sweet potatoes (there) later.'

(55) (A mother begging a bandit)

Lí nā m̄ hōo góa kap góaê kián chòehóe, tiòh chiong góan thâi sí. $2 \mathrm{~s}$ if not HOO $1 \mathrm{~s}$ with $1 \mathrm{~s}$ son be.together have.to CHIONG 1PE kill dead 'If you do not let me stay with my son, you have to kill me.'

(56) (Miser to servant)

Lí chin gōng, chin pn̄gtháng! Soah bōe hiáutit chiong hiahê kū chhâliāu $2 s$ very stupid very incompetent how not know take those old wood thèh lâi, kakī tahtah tèngtèng leh. take come self cover nail UFP 'What? Ah! You are so stupid and you are dumb! Why did you not know that you could take the old wood and use nails to do the woodwork yourself?'

The other benefactive cases include the verbs thòe/thè 'to (do something) for', pangchàn 'to help', and chiap 'to pick up (someone)', in the form [ $\mathrm{S}_{\text {beneficiary }} \mathrm{NP}$ $\mathrm{V}_{2}$ ], with thè making up the majority, in BEGGING or REQUEST:

(57) (Farmer to a friend)

Lí teh siūn ${ }^{\mathrm{n}}$ símmih? Tiòh kóa ${ }^{\mathrm{n}}$ kín thè góan siūn ${ }^{\mathrm{n}}$ pānhoat.

2s ASP think what have.to hurriedly for 1PE think way

'What you are thinking about? (You) should think of a way for us (to deal with this problem).'

In (57), the benefactive verb thòe can be substituted by the coverb $k \bar{a}$. Compared with the $k \bar{a}$-construction, however, the $\left[\mathrm{S} \mathrm{V}_{\text {beneficiary }} \mathrm{NP}_{2}\right]$ functions as a serial verb construction with both verbs highlighted, whereas $k \bar{a}$ functions as a coverb or preposition foregrounding the action denoted by the succeeding verb.

The other complex verb constructions are serial verb constructions with dynamic verbs or stative verbs, e.g., the construction [cho NP V], as in (58):

(58) (Host to a visitor)

Chhián lí màbián khòalū chò lí ansim tòa, ta ${ }^{\mathrm{n}}$ hia chē.

please $2 \mathrm{~s}$ no.need worry do $2 \mathrm{~s}$ relaxed stay now there sit

'Please do not worry and stay overnight with us. Now be seated there.'

In the above discussion, we have established important verbal patterns that are recurrent in TSM directives: directional verbs, directional complements, disposal constructions, and beneficiary-marking verbs. Regarding the use of directional verbs, a cross-linguistic difference is observed between the use of lâi/lâikhì 'come/ 
let's' and let's in English, the latter of which was found to be the most frequently used English imperative in a story corpus. Disposal constructions with hoo, on the other hand, are unique to TSM as Mandarin may use gei 'give' to mark a beneficiary (Tsao 1988, e.g., (53)) ${ }^{11}$ while English resorts to transitive verbs (e.g., (54)) to express a similar idea. The chiong construction, on the other hand, corresponds to the $b a$ construction in Mandarin (Tsao 1987).

\subsection{Utterance-final particle}

UFPs are not found to be an obligatory component of directives $(36 / 408,9 \%)$, most of which are realized by le/leh (Table 11, Appendix II). Basically, le/leh carries an emphatic tone and signals contrast ( $\mathrm{Li}$ 1999: 211) between what $\mathrm{S}$ is directing $\mathrm{H}$ to do and what $\mathrm{H}$ is actually doing. In addition, several constructions or expressions are associated with leh: (i) delimitation or trivialization of a directed act such as reduplication of verbs, as in (56) (tèngtèng 'to nail') or the delimitation marker chitē in, e.g., (45), (ii) the comparative marker khah, e.g., (33), (iii) verbs denoting deceleration of an action such as bānsī 'hold on', e.g., (59a), (iv) verbs of imploring pàithok 'plead', as in (59b), and (v) the intentisification marker $m \bar{a}$ (Ni 1996), as in (59c). These expressions may co-occur with one another to reinforce the emotive tone, e.g., Lí $m \bar{a}$ khah pàithok leh 'please, would you (grant my request)?' The leh-attached directives are all implicative of a certain degree of contrast between S's assumption about what $\mathrm{H}$ should do and what $\mathrm{H}$ is actually doing.

(59) Directives with leh

a. Chhián lí bānsīlâi leh! please 2s slow.down UFP 'Please take your time.'

b. Sianse ${ }^{\mathrm{n}}$, khah pàithok leh. sir more plead UFP 'Sir, come on!'

c. Lí mā lâi tàu koochiân leh. Góa khòa ${ }^{\mathrm{n}}$ chitê gíná khàu kah bô sian 2s MA come help comfort UFP $1 \mathrm{~s}$ see this child cry till no sound lah! UFP

'You (hurry up and) come help comfort (the child)! I saw the baby was hoarse from crying.'

11. As we focus on TSM directives, for a full discussion of Mandarin gei 'give', the reader is referred to Tsao (1988). 
The other UFPs include $o / o h$, la/lah, ho/hon , ah, and le-noh and $m$ in the form of tag questions. Compared to Mandarin UFPs such as $b a$ and $a$, which are used to mitigate the force of a directive (Shei 2014), TSM may employ tag questions like hó bô 'okay?' to soften the commanding tone (e.g., (45)), though these are of low frequency in the corpus. Furthermore, as these non-leh UFPs are uncommon, they are not associated with a particular directive subtype. In general, UFPs "serve the indexical function" (Li 1999:252) of addressing the H's assumption or knowledge so that S's communicative intent is more successfully conveyed.

\subsection{Summary}

So far, we have discussed the main components of directives in the corpus. The findings can be summarized as follows:

1. The nine directive subtypes are ADVICE, BEgGing, INVITATION, ORDER, OFFER, REQUEST, SUGGESTION, URGE, and WARNING.

2. Alerters are rare. They mainly take the form of an address term, especially first names, kinship terms, or titles. The latter two forms are strongly associated with a polite attitude.

3. An utterance-initial discourse marker $t a^{n}$ 'now' is preferentially used to mark the relevance of the current situation.

4. A politeness marker, especially chhián 'please', may be used to reinforce S's positive attitude. When used, it tends to attract an overt $\mathrm{H}$-dominated subject, forming the bundle chhián lílin 'please-you'.

5. Subjects are either H-dominated or S\&H-dominated, with the latter expressing solidarity (Brown \& Levinson 1987) in casual situations. Where the subject is omitted, the directive may include a modifier to show S's apprehension or the verb lâi to convey a friendly tone.

6. The default modal auxiliary form is tióh 'have to', used to denote obligation or the necessity of the requested action.

7. The most common verbs are dynamic (directional and displacement), stative, uttering, ingesting, and vision verbs.

8. Directional verbs and displacement verbs are pervasive across all subtypes except WARNING, for which stative verbs are preferred.

9. Directional verbs marking action toward S, e.g., lâi 'come' are strongly associated with a positive attitude toward $\mathrm{H}$, e.g., INVITATION, OFFER, BEGGING, and SUGGESTION, whereas those expressing movement away from S, e.g., khi 'go' tend to denote an adversative mood, e.g., ORDER.

10. Uttering verbs comprise a significant proportion. They are used in all the directive subtypes except for OFFER and WARNING. 
11. Ingesting verbs are used almost exclusively in OFFER.

12. Vision verbs are prone to occur with lâi 'come' and are used almost exclusively in INVITATION or REQUEST.

13. Benefactive verbs are most strongly associated with BEGGING.

14. Complex verb constructions mainly include (a) directional verbs; (b) disposal constructions, and (c) benefactive constructions, with directional verbs prevailing across 2-verb or 3-verb constructions.

Given the above summary, we propose a preferred usage pattern(s) for each directive subtype, as shown in Table 12 (Appendix II). Although these findings should be generalized with caution as they do not exclude the presence of the less common forms, they serve as an important reference for language teachers and learners.

\section{Discussion and conclusion}

In this paper, we have probed an under-explored area of TSM pragmatics, focusing on directives in play scripts in TSM, thereby contributing to our understanding of the subtypes of directives and their preferred usage patterns based on corpus data. Generally speaking, while the preferred patterns in TSM reflect the sequence of requests discussed in the literature (Blum-Kulka, House \& Kasper 1989), TSM differs from other languages primarily in terms of the use of utterance-final particles and in the frequency of its linguistic realizations. In addition, the results raise a few cross-linguistic and theoretical points that merit further discussion.

First, the frequency differences regarding alerters and tags between our study and previous research in Chinese (Zhang 1995, Jang 2014, and Chen \& Tseng 2015) point to the influence of data sources on the frequencies of speech act components. For example, the greater frequency found by previous studies may be an effect of more homogeneous scenarios, e.g., interactions in academic contexts, used in the DCT questionnaires, whereas the TSM play scripts include interactions between speakers of different social statuses, different degrees of familiarity, and events of varying degrees of urgency.

In terms of the degree of directness, that there is only a limited number of indirect directives agrees with the finding of studies on Mandarin requests (Yu 1999, Rue \& Zhang 2008, Jang 2014). A reverse trend, however, is noted in L1 and L2 English (Blum-Kulka, House \& Kasper 1989). These divergent results call for future investigation of language-specific factors that influence the choice of speech act strategies. 
Regarding expressions of politeness, one cross-linguistic difference found by the present study is that, in addition to $c h i^{\prime} a^{n}$ 'please', TSM speakers use the directional verb lâi 'come; hither' to achieve the same communicative purpose following the formula $[l a \hat{i} \mathrm{~V}] .{ }^{12}$ The process at work here is a metaphorical transfer of lâi from a concept in the spatial domain to one in the interactional domain (Lee Chen 1997). By drawing H closer to S physically with lâi, S acknowledges $\mathrm{H}$ as a member of the group, thus enhancing solidarity among them and rendering the directive act less forceful. The omnipresence of [lâi $\mathrm{V}]$ suggests that it has been conventionalized as a formulaic chunk for the expression of politeness. Such a mechanism tallies perfectively with the "approach-based" nature of positive politeness (Brown \& Levinson 1987: 70).

The analysis also reveals cross-register difference in the verb types in the head acts. While we have observed a dominance of dynamic verbs in our play script corpus, Stefanowitsch \& Gries (2003:232) have found that stative verbs, e.g., see, look, and listen, which imply "low imposition", rank high on the imperative verb list in contemporary English. The distribution of speech act verbs, therefore, is an issue that warrants further exploration.

In conclusion, the directive patterns proposed in this study have pedagogical implications for Taiwanese learning and teaching. Specifically, when a speaker intends to produce a directive speech act, there is an inventory of words and phrases from which to select to fulfill the interactional goal. The suggested usage patterns further serve as important guidelines and as a reference for TSM language teachers.

\section{Funding}

This study was funded under the ROC's Ministry of Science and Technology grant number MOST 104-2420-H-OO3-OO1-.

\section{Acknowledgements}

We are also grateful to the anonymous reviewers for their helpful comments and suggestions. All remaining errors are ours.

12. According to Yu (1999: 293), speakers use the honorific pronoun nin 'you' and qing 'please' to show politeness. 


\section{List of abbreviations}

a. For directives:

Dir Directive(s)

AD Advice

BG Begging

IV Invitation

OD Order

OF Offer

RQ Request

SG Suggestion

UG Urge

WR Warning

b. For morphemic gloss:

1s $\quad$ ist person singular

1PI 1st person plural inclusive

1PE 1st person plural exclusive

$2 \mathrm{~s}$ 2nd person singular

3s $\quad 3$ rd person singular

AC associative marker $\hat{e}$

ASP aspect marker

CHIONG the marker chiong

CL classifier

COMP comparative

HоO the marker hoo

INTJ exclamatory marker

KA the marker $k \bar{a}$

MA the marker $m \bar{a}$

PN proper name

UFP utterance-final particle

\section{References}

Austin, John L. 1962. How to Do Things with Words. London: Oxford University Press.

Biber, Douglas, Stig Johansson, Geoffrey Leech, Susan Conrad, and Edward Finegan. 1999.

Longman Grammar of Spoken and Written English. Harlow, UK: Pearson.

Blum-Kulka, Shoshana, Juliane House, and Gabriele Kasper. 1989. Cross-Cultural Pragmatics:

Requests and Apologies. Norwood, NJ: Ablex Publishing Corporation.

Brown, Penelope, and Stephen C. Levinson. 1987. Politeness: Some Universals in Language

Usage. Cambridge, UK: Cambridge University Press.

https://doi.org/10.1017/CBO9780511813085

Bybee, Joan L. 1995. An introductory essay. Modality in Grammar and Discourse, ed. by Joan L. Bybee and Suzanne Fleischman, 1-14. Amsterdam: John Benjamins. https://doi.org/10.1075/tsl.32 
Chang, Miao-Hsia. 2015. Two counter-expectation markers in Chinese. Metaphor and Metonymy across Time and Cultures: Perspectives on the Sociohistorical Linguistics of Figurative Language. Cognitive Linguistics Research Series, ed. by Javier E. Díaz-Vera, 141-170. Berlin: Mouton de Gruyter. https://doi.org/10.1515/9783110335453.141

Chang, Miao-Hsia, and Shu-kai Hsieh. 2017. A corpus-based study of the recurrent lexical bundle ka li kong 'let (me) tell you' in Taiwanese Southern Min conversations. Chinese Language and Discourse 8.2:174-211. https://doi.org/10.1075/cld.17004.cha

Chen, Mei-Ying, and Chia-Ti Tseng. 2015. A comparative study on the request strategies of college students and the semantic formulas of Mandarin textbooks in Taiwan. Journal of Chinese Language Teaching 12.3:125-151.

Chen, Xiu (ed.) 1991. Taiwanhua Dacidian [A Dictionary of Taiwanese]. Taipei: Yuan-Liou Publishing Co., Ltd.

Chen, Yupin. 2010. Mandarin-Speaking Children's Politeness in Requests. Doctoral dissertation, National Chengchi University, Taipei.

Geng, Chunling. 2015. Comparison between Chinese address terms and English address terms. Higher Education of Social Science 9.4:1-4.

$\mathrm{Gu}$, Yueguo. 1990. Politeness phenomena in modern Chinese. Journal of Pragmatics 14.2:237-257. https://doi.org/10.1016/0378-2166(90)90082-O

Huang, Han-Chun. 2015. Causative and interpersonal constructions: Manifestations of kang7 in Modern Taiwanese Southern Min. Journal of Taiwanese Languages and Literature 10.2:47-74.

Jang, Hee Jin. 2014. The analysis of Chinese request strategies and pedagogical applications in Chinese TV dramas. MA thesis, National Taiwan Normal University, Taipei.

Kärkkainen, Elise. 2003. Epistemic Stance in English Conversation: A Description of Its Interactional Functions, with a Focus on I Think. Amsterdam \& Philadelphia: John Benjamins. https://doi.org/10.1075/pbns.115

Kohnen, Thomas. 2008. Tracing directives through text and time: Towards a methodology of a corpus-based diachronic speech-act analysis. Speech Acts in the History of English, ed. by Andreas H. Jucker and Irma Taavitsainen, 295-310. Amsterdam \& Philadelphia: John Benjamins. https://doi.org/10.1075/pbns.176.16koh

Lee, Hui-Chi. 2009. Ka...hoo constructions in Taiwanese Southern Min. Taiwan Journal of Linguistics 7.2:25-47.

Lee, Kai-fat. 1976. Polysyllabicity in the modern Chinese verb: An attempt to quantify a linguistic drift. Journal of Chinese Linguistics 4.1:24-46.

Lee Chen, Lily. 1997. Metaphorical extension: The phenonmenon of lâi來/khi去 'come/go' in Taiwanese. Symposium Series of the Institute of History and Philology, Academia Sinica: Chinese Languages and Linguistics, vol. III, ed. by Feng-fu Tao and H. Samuel Wang, 103-137. Taipei: Academia Sinica.

Lee-Wong, Song Mei. 1994. Imperatives in requests: Direct or impolite-Observations from Chinese. Pragmatics 4.4:491-515. https://doi.org/10.1075/prag.4.4.01lee

Levin, Beth. 1993. English Verb Classes and Alternations: A Preliminary Investigation. Chicago, IL \& London: The University of Chicago Press.

Li, Ing Cherry. 1999. Utterance-Final Particles in Taiwanese: A Discourse-Pragmatic Analysis. Taipei: Crane Publishing.

Lin, Yuh-Huey. 2009. Query preparatory modals: Cross-linguistic and cross-situational variations in request modification. Journal of Pragmatics 41.8:1636-1656.

https://doi.org/10.1016/j.pragma.2008.12.007 
McCarthy, Michael. 1991. Discourse Analysis for Language Teachers. Cambridge, UK: Cambridge University Press.

Ni, D. Fu-yeh. 1996. Discourse functions of Taiwanese adverbs $m a, a$, and koh. MA thesis, National Taiwan Normal University, Taipei.

Nuyts, Jan, Pieter Byloo, and Janneke Diepeveen. 2010. On deontic modality, directivity, and mood: The case of Dutch mogen and moeten. Journal of Pragmatics 42.1:16-34. https://doi.org/10.1016/j.pragma.2009.05.012

Panther, Klaus-Uwe, and Linda L. Thornburg. 1998. A cognitive approach to inferencing in conversation. Journal of Pragmatics 30.6:755-769. https://doi.org/10.1016/S0378-2166(98)00028-9

Panther, Klaus-Uwe, and Linda L. Thornburg. 1999. The potentiality for actuality metonymy in English and Hungarian. Metonymy in Language and Thought, ed. by Klaus-Uwe Panther and Günter Radden, 333-357. Amsterdam \& Philadelphia: John Benjamins. https://doi.org/10.1075/hcp.4.19pan

Panther, Klaus-Uwe, and Linda L. Thornburg (ed.) 2003. Introduction: On the nature of conceptual metonymy. Metonymy and Pragmatic Inferencing, 1-20. Amsterdam \& Philadelphia: Jonh Benjamins. https://doi.org/10.1075/pbns.113.03pan

Pérez Hernández, Lorena, and Francisco José Ruiz de Mendoza. 2002. Grounding, semantic motivation, and conceptual interaction in indirect directive speech acts. Journal of Pragmatics 34.3:259-284. https://doi.org/10.1016/S0378-2166(02)80002-9

Rue, Yong-Ju, and Grace Qiao Zhang. 2008. Request Strategies: A Comparative Study in Mandarin Chinese and Korean. Amsterdam \& Philadelphia: John Benjamins. https://doi.org/10.1075/pbns.177

Schourup, Lawrence. 2011. The discourse marker now: A relevance-theoretic approach. Journal of Pragmatics 43.8:2110-2129. https://doi.org/10.1016/j.pragma.2011.01.005

Searle, John R. 1969. Speech Acts: An Essay in the Philosophy of Language. Cambridge, UK: Cambridge University Press. https://doi.org/10.1017/CBO9781139173438

Searle, John R. 1979. Expression and Meaning: Studies in the Theory of Speech Acts. Cambridge, UK: Cambridge University Press. https://doi.org/10.1017/CBO9780511609213

Shei, Chris. 2014. Understanding the Chinese Language: A Comprehensive Linguistic Introduction. London \& New York: Routledge. https://doi.org/10.4324/9781315767222

Stefanowitsch, Anatol, and Stefan Th. Gries. 2003. Collostructions: Investigating the interaction of words and constructions. International Journal of Corpus Linguistics 8.2:209-243. https://doi.org/10.1075/ijcl.8.2.03ste

$\mathrm{Su}$, Xiu-mei. 1988. The Acquisition of Directives in Pre-School Children in Pragmatic and Syntactic Perspectives. MA thesis, Fu Jen Catholic University, Taipei.

Takahashi, Hidemitsu. 2012. A Cognitive Linguistic Analysis of the English Imperative: With Special Reference to Japanese Imperatives. Amsterdam \& Philadelphia: John Benjamins. https://doi.org/10.1075/hcp.35

Taylor, John R. 1989. Linguistic Categorization: Prototypes in Linguistic Theory. Oxford: Clarendon Press.

Teng, Kuan-ming. 2017. On Negative Imperatives in Taiwanese Southern Min. Doctoral dissertation, National Tsinghua University, Hsinchu.

Teng, Shou-hsin. 1982. Disposal structures in Amoy. Bulletin of the Institute of the History and Philology, Academia Sinica 53.2:331-352. 
Thornburg, Linda L., and Klaus Panther. 1997. Speech act metonymies. Discourse and Perspective in Cognitive Linguistics, ed. by Wolf-Andreas Liebert, Gisela Redeker and Linda Waugh, 205-222. Amsterdam \& Philadelphia: John Benjamins. https://doi.org/10.1075/cilt.151.14tho

Toolan, Michael J. 1994. Narrative: Linguistic and structural theories. The Encyclopedia of Language and Linguistics, vol. 5, ed. by R. E. Asher and J.M.Y. Simpson, 2679-2696. Oxford: Pergamon Press.

Traugott, Elizabeth Closs. 1991. English speech act verbs: A historical perspective. New Vistas in Grammar: Invariance and Variation, ed. by Linda R. Waugh and Stephen Rudy, 387-406. Amsterdam \& Philadelphia: John Benjamins. https://doi.org/10.1075/cilt.49.24clo

Tsao, Feng-fu. 1987. A topic-comment approach to the ba construction. Journal of Chinese Linguistics 54.1:1-54.

Tsao, Feng-fu. 1988. The function of Mandarin gei and Taiwanese hou in the double object and the passive constructions. The Structure of Taiwanese: A Modern Synthesis, ed. by Robert Liang-wei Cheng and Shuanfan Huang, 165-208. Taipei: Crane Publishing.

Wardhaugh, Ronald. 2006. An Introduction to Sociolinguistics (5th edition). Oxford: Blackwell Publishing.

Wierzbicka, Anna. 1987. English Speech Act Verbs: A Semantic Dictionary. Marrickville, Australia: Academic Press.

Wierzbicka, Anna. 1991. Cross-Cultural Pragmatics: The Semantics of Human Interaction. Berlin \& New York: Mouton de Gruyter. https://doi.org/10.1515/9783112329764

$\mathrm{Yu}$, Ming-chung. 1999. Universalistic and culture-specific perspectives on variation in the acquisition of pragmatic competence in a second language. Pragmatics 9.2:281-312. https://doi.org/10.1075/prag.9.2.04yu

Zhang, Yanyin. 1995. Strategies in Chinese requesting. Pragmatics of Chinese as Native and Target Language, ed. by Gabriele Kasper, 23-68. Honolulu, HI: University of Hawaii Press.

\title{
Online appendix
}

Online appendix is available at: https://doi.org/10.1075/consl.ooo30.cha.additional.

\section{Address for correspondence}

\author{
Miao-Hsia Chang \\ Department of English \\ National Taiwan Normal University \\ Taipei, TAIWAN \\ mhchang@ntnu.edu.tw
}




\section{Co-author information}

Ún-giân Iûnn

Department of Taiwanese Languages and Literature

National Taichung University of Education

Taichung, TAIWAN

ungian@ntcu.edu.tw

\section{Publication history}

Date received: 29 April 2021

Date revised: 31 May 2021

Date accepted: 7 June 2021

Published online: 17 November 2021 